\title{
About trends of improvement of technological schemes for methane recovery from the rock- coal massif
}

\author{
Serhii Kurnosov ${ }^{1, *}$, and Volodymyr Zerkal ${ }^{2}$ \\ ${ }^{1}$ Institute of Geotechnical Mechanics named by N. Poljakov of National Academy of Sciences of \\ Ukraine, 49005, Dnipro, Simferopolska Str., 2a, Ukraine \\ ${ }^{2}$ Private Joint Stock Company «DTEK Pavlogradugol», 51400, Pavlohrad, Soborna Str., 76, Ukraine
}

\begin{abstract}
Purpose of the research was to improve efficiency of underground gas drainage from the rock-coal massif. It is substantiated that most promising solutionof the problem of increasing efficiency of gas drainage from the massif is to mine additional gas-drainage road. This approach allows separatingprocesses of coal mining and methane recovery in space and time. The Ukrainian normative documents is recommended to mine the roadbehind zones with high rock pressure. We found that in difficult conditions of coal seam mining, distance from road to working longwall would be more than $100 \mathrm{~m}$. This distance reduces efficiency of gas drainage and is not economically feasible due to significant length of gas-drainage boreholes and air breakthroughs. Therefore, gas-drainage road should be located as close to the working longwall as possible, but with possibility to ensure its stability during its entire service life. Experimental studies were conducted in Zasyadko Mine and Krasnolymanska Mine. It is established that with increasing distance from working wall to the gas-drainage road location in the massif, unloaded by the underworking displacement, the road contour decreases, and methane flow rate increases in power dependencies. Use of these results will make calculation of the gas-drainage road rational location more accurate.
\end{abstract}

\section{Introduction}

Modern technologies of coal mining in flat seams and technical feasibility of thestate-ofthe-art mining equipment are 3-5 times higher than the achieved productivity of longwalls. This is due to a number of objective factors associated with increased gas content in the massif and rock pressure as mining activity extends to greater depth. With intensification of mining operations in such conditions, ventilation system cannot reduce methane content in the mine atmosphere to the standard level stipulated by the "Safety Regulations ..." [1]. When mining operations are conducted in the rock massif, closely interrelated geomechanical and gas-dynamic processes occur. Deformation of the rock massif intensifies gas release from coal beds and rocks [2]. Nature of these processes leads to a

\footnotetext{
*Corresponding author: sakurnosov@gmail.com
} 
complex gas-dynamic situation in the mining district and reduces pace and degradesafety of mining operations. Thus, risk of gas contamination of the mine tunnels reduces output of mining districts and adversely affects economic indexes of the coal mines. Solution of this problem laysin use of efficient schemes for gas drainage from the massif.

For developing a gas-drainage scheme from the rock-coal massif, it is important to have a great amount of information about the object subject to the gas drainage, including: characteristic of stress field in the massif, its natural gas content, porosity, humidity, intraformational gas pressure, ambient temperature, location of the object relatively to the working and previously mined-out longwalls in space and time, etc.

In Donbass coal deposits, the biggest reservoir of methane accumulation is gas-bearing sandstone. Here, volume of sandstone is $60-70 \%$ of the total volume of coal-bearing deposits, its thickness reaches 40 meters or more, and gas content is within $2-5 \mathrm{~m}^{3} / \mathrm{m}^{3}$. A distinctive feature of the sandstone porosity is predominance of macropores in their structure (about $80 \%$ ), while micropores make up only about $20 \%$. Bulk porosity of sandstones is within 3-12\%. In addition, sandstone very easily releases gas in the process of deformation. This is facilitated by the fact that up to $90 \%$ of gas in sandstones is in free state.

Gas-drainage scheme should be chosendepending on intended technology of mining operations, procedure for preparing mine section, development systems, etc. The scheme should provide maximum methane recovery from the rock massif, which can be achieved by properly chosengas-drainage borehole location and direction with taking into account network of tunnels of the working area. Main parameters of gas-drainage boreholesare their length, diameter and angles of inclination and rotation. Also an important parameter of the gas-drainage scheme is method used for intensifying methane release from the rock massif:vacuumization of boreholes, hydraulic fracturing of massif, effect of various chemical reagents, etc. Intensification of methane release from the rock massif also occurs under the influence of mining activity. In this case, a significant redistribution of stressstrain state occurs in the massif: zones withhigh rock pressure and rock pressure release appear and change in time. These processes, in turn, form directions of gas migration in the rock-coal massif and ability of the massif to release methane through the gas-drainage boreholes. It is very difficult to take all of these factors into account while developingschemes for methane recovery, but such schemes can significantly increase efficiency of gas drainage at acceptable financial costs.

\section{Methane recovery schemes with using preparatory roadway mined along the coal seam}

Normative documents [3] propose gas-drainage schemes, whichassume drilling of boreholes from preparatory roadwaysmined along the coal seam. Such schemes should be developed with taking into account the following main factors: location of gas accumulation sources; accessibility to these sources through the boreholes drilled from preparatory roadways; ensuring long life of boreholes. Drainage boreholes drilling must be correlated in space and in time with other operations of coal mining technological cycle. Depending on the mining method used, there aresix main variants of gas-drainage schemes, which are described below.

Main advantage of all gas-drainage schemes with long-pillar method is possibility to drill boreholes in advance during the preparation of mine sections.

With long-pillar method along the strike, the most commonly-used gas-drainage scheme assumes drilling of boreholes from the haulage gate along thebed rise and parallel to the longwall face. When gas is drained fromgoaf or accompanying beds, it is sometimes reasonable to drill boreholes from the air roadway along the bed dip because ofinterference 
created forthe coal mining processes. In this case, air roadway should be equipped with a gas-drainage pipeline. When this gas-drainage scheme is chosen, it should be taken into account that drilling of down-holes is technologically more complicated than ascending ones because of gumming of drilling tool and long period needed fordrying the boreholes before their active operation starts. Boreholes should be drilled in advance along with advancing of preparatory roadways during preparation of mine sections. In the course of mining operations, boreholes for preliminary gas drainage are drilled ahead of the longwall face. The advance drilling should ensure long life of the boreholes.

If process of borehole drilling from the roadway holds back operations of mining cycle, it is possible to use fan pattern of borehole drilling. In these cases, it is necessary to construct special niches for drilling equipment. Size of niches is determined by size of the drilling equipment. Recommended distance between the borehole clusters is $30-40 \mathrm{~m}$. Density of the fan borehole grid should correspond to density of grid of boreholes directed parallel to the stope line in these conditions. Disadvantage of the scheme is a great volume of preparatory work connected with niche construction and supporting.

When pillar method with double longwalls is used, gas-drainage scheme assumes borehole drilling along the seam strike from the common roadway. This roadway is mined between the double longwalls. Gas-drainage boreholes are connected to the common gas pipeline. Such scheme may also assume drilling of additional boreholes from the boundary entries, but in this caseadditional independent gas pipelines should be laid. Advantage of this scheme is creation of more favorable conditions for technological cycle of coal seam mining; and disadvantage is the need to lay additional gas pipelines.

When boreholes are drilled along the strike from preparatory roadways, it is necessary to locate the boreholes at small angle $\left(3-5^{\circ}\right)$ to the longwall line in such a way that the longwall face is above its mouth in order to ensure water drainage whendrilling operations are ended. Though, it significantly reduces efficiency of the gas-drainage process.

Gas-drainage scheme for seams mined by longwalls assumes borehole drilling along the bed rise from the advanced part of the haulage gate. With this scheme, gas drainage can be effective only whenheading development in the haulage gate is significantly ahead the longwall face line. This advance should ensure at least 6 months of active work of the gasdrainage boreholes. Significant drawback of this scheme is difficulties with airing of long section of the haulage gate dead end.

In case of longwall mining, gas-drainage scheme for the mining coal seam is also used, which assumesgas-drainage borehole drilling from any point of the haulage gate along the seam dip into the underlying mine section. Advantage of this scheme is preliminary gas drainage from the rock-coal massif long before coal seammining starts. Thanks to the preliminary gas drainage, use of this scheme also allows reducing time period for starting miningoperations in the new underlying horizon.

The above gas-drainage schemes, which assume drilling of gas-drainage boreholes from preparatory roadways, can be used in various combinations, though, depending on location of the main sources of gas emissions, development of roadway network in space and time, order of mine section mining, length of longwall and other mining, geological and technical factors. In each case, gas-drainage scheme should be chosenbasing on requirement of maximum methane recovery from the rock-coal massif with the lowest labor content and minimal financial costs for implementation of gas drainage measures.

Thus, gas drainage works in the Ukrainian mines are executed from horizon of mining seam; therefore, it is impossible to realize a combinedgas drainage scheme, which ensures methane recovery simultaneously from the mining seam, roof and floor rocks, accompanying beds, and from previously worked-out long-pillar. Combination of technological measures on coal extraction withgas drainageexecuted in preparatory roadways makes implementation of these operations ineffective. Gas-drainage boreholes 
drilled from air roadway or haulage gateare quickly ruinedunder the action of mining activity, hence, leadingto degradation of their performance. With pillar method, preparatory roadways behind the longwall are usually brought down, making current gas drainage impossible, and as a result of preliminary gas drainage, no more than $30 \%$ of gas is recovered. All above mentioned substantiates the need to develop fundamentally new efficient gas-drainage schemes.

\section{Trends of improvement of technological schemes for methane recovery from the rock-coal massif}

Effective gas drainage from the rock massif should be the key principle for solving problems of safe mining in difficult conditions. Search for ways of improving gas-drainage schemes has led to the most effective variant: separation of coal mining and methane recovery processes in space and time. This variant assumes using of gas-drainage roadminedin the rock roof or floor of the previously worked-out long pillar, mining seam or future long-pillar (Fig. 1). Effectiveness of such schemes is significantly higher when they comply with the following scientific and technical requirements:

- possibility of mining gas-drainage road outside zones of mining operation influence and zones of active rock movement in the underworked (overworked) massif;

- effective gas drainage from the massif with any mining method used;

- separation of processes of coal mining and gas drainage from the massif in space and timefor safety and intensive mining of coal seams;

- solving of problem of methane recovery from the mining seam, enclosing rock, accompanying beds and goafs both in front of the longwall and behind it;

- varying direction of gas-drainage borehole drilling in order to increase volume of methane recovery;

- ensured long-term functioning of gas-drainage road.

To meet these requirements, it is necessary to solve a number of problems in order to determine proper location of gas-drainage road and rational parameters for the boreholes, namely: to study geomechanical features of processes of movement, stratification and cracking occurred in the underworked and overworked rock massif; to identify possible cavities with methane accumulation and paths of its migration; todetermine rational location for the gas drainageroad and to calculate parameters for its supports; to calculate parameters of gas-drainage boreholes (Fig. 1).

Gas-drainage road should meet the following requirements: it should not be minedin areas with high rock pressure and near sources of methane accumulation; it should create conditions for drilling effective drainage boreholes to the previously worked-out long-pillar and the working long-pillar; it should solve problem of methane recovery from the mining seam, enclosing rocks and accompanying beds both in front of and behind the longwall; it should be stable throughout the entire period of executing ofgas drainage operations.

According to the degree and nature of destruction within area of mining activity influence, a massif can be divided into the following zones [4]:

- Release zone: it is an area of mining activity influence, within which normal stresses are less than stresses of virgin massif. Release zones cover area of rocks over and under the mining district, respectively, over- and underworked massif. Size of such zone is determined by rock hardness anddifferent technological factors, primarily thickness of coal seam, geometric dimensions of longwall and rate of its advance. In release zone, the following processes occur: stratification of roof rocks, slippage at the contactsbetween over- and underworked seams, formation and opening of cracks normal for bedding. All this facilitates intensive release of free gas from the cracks, which then flows into the formed cavitiesin the goafs. 


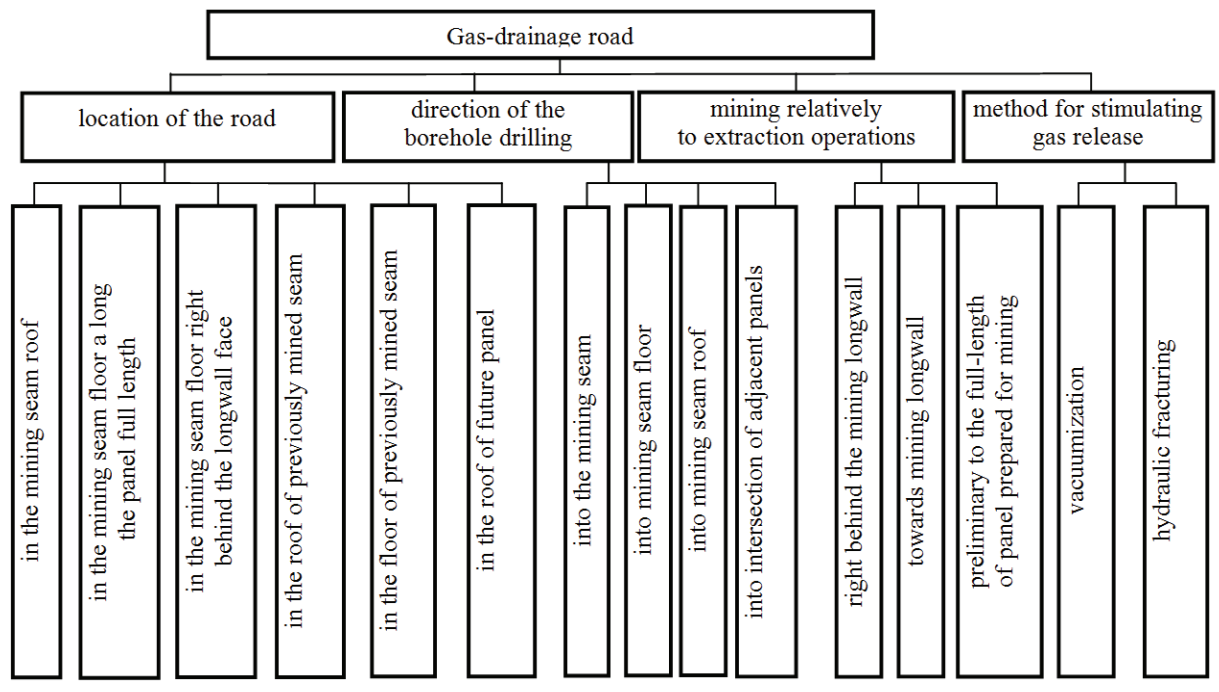

Fig. 1. Scheme of gas-drainage from the massif with additional gas-drainage road.

- Random caving zone: it is formed in the roof layers closest to the mining seam. Initially, it is characterized by disintegration of rocks into lumps, and then - by their loosening. Normally, height of such zone usually does not exceed sixfoldthickness of the seam. Random caving zone is not obligatory formed in case of hard rocks, short goafs andsmall thickness of crushed rocks or their gradual caving.

- Total displacement zone: it is located in the roof of mining seam above the random caving zone and is limited by angles of total displacement on the goaf boundaries. Initially, fracturing in this zone is mainly directed along the rock bedding, therefore, no methane migrates into the goaf. Over time, deflection of rocks increases, vertical cracks are formed, and this part of the massif becomes a source of methane migrated into the goaf. Height of the total displacement zone can reach the earth's surface.

- Longwall-support reference pressure zone: it is an area of massif, which is under the influence of stope. In this zone, normal stresses are significantly higher than stresses in virginmassif. It is formed as a result of transfer of undermining rock pressure to marginal parts of mining seam. In reference pressure zone, rocks are in state of volumetric compression, and, near the marginal part of the seam, they are in loosening state, which is manifested in the form of face slip. Zones of slip and loosing are the main sources of gas escaping from the coal seam and enclosing rocks into the face area.

- Stationary reference pressure zone: it is formed on the border of previously worked-out and working long-pillars a result of rocks hangingover the goaf. Geometrical parameters of this zone have a significant impact on methane migration paths between the adjacent longpillars.Projects for the gas drainagefrom the rock-coal massif should include justification and choice of: order of gas-drainage road advance and its location in the massif relatively to the longwall; methods and facilitiesfor its supporting in various mining, geological and technical conditions; method and technology for methane recovery.

\section{Scientific and technical principles for gas-drainage road location}

The main way of improving gas-drainage road stability is to locate it in zones of regional release, where stress is lower than in virgin massif. 
Whengas-drainage road is locatedin zone of longwall active influence, the following stages of support loading are observed: when the road is located at a distance of more than $200 \mathrm{~m}$ from the mining longwall face, it is not affected by the mining activity; at a distance of $50-150 \mathrm{~m}$, the road is subject to the active influence of longwall, and pressure on the supportscan be 1.2-1.3 times greater than their yielding, when depths of mining operations is over $1000 \mathrm{~m}$; when it is located in reference pressure zone (distance from the longwall face is up to $50 \mathrm{~m}$ ), load on the road support is $2.0-2.5$ times greater than its bearing capacity; and when gas-drainage road is located behind the longwall, at a distance of roof fall pace, the load reaches a maximum value and can be 4.0-4.5 times greater than bearing capacity of support.

Along the normal to the rocks bedding, gas-drainage road should be mined in so way that weaker rocks are located in its sides, and hardrocks are in the roof and floor. The lower is hardness of the roof and floor rocks, the longershould be distance from the coal seam bottom to the floor of the road. An important parameter in determining this distance is propensity of the rocks forslakening, which depends on degree of their metamorphism and amount of clay components.

According to the "Directions for rational location, ..." [4], for the safe road location, minimum distance $\ell_{\min }$ from mining longwall to the previously mined-out goaf is determined by the expression:

$$
\ell_{\min }=9.1 k k_{t} k_{H} k_{u} \exp (0.053 H / R),
$$

where $k=1-1.5$ is stability factor of the road, which depends on its type and purpose; $k_{t}$ - is factor of time effect on the rock displacement; $k_{H}$ - is coefficient of effect of adjacent longwall mining direction; $k_{u}$ - is ratio of the road roof and floor displacements; $H$ - is depth of the road location, $\mathrm{m} ; R$ - is rock hardness for uniaxial compression, $\mathrm{MPa}$.

In order to improve efficiency of methane recovery from the working long-pillar and to reduce length of the gas-drainage boreholes drilled to the working long-pillar and air breakthroughs between the gas-drainage road and air roadway, distance $\ell$ should be minimized. However, this may degrade stability of the gas-drainage road [5]. Therefore, it is necessary to know patterns of rock pressure formation along the seam strike in the process of its development and along it rise in the goaf of previously worked-out longwalls. For this purpose, the Institute of Geotechnical Mechanics named by N. Poljakov of National Academy of Sciences of Ukraine carried out certain experimental studies. Object of the research was process of rock stress-strain state changing during mining a coal seam $\mathrm{m}_{3}$ in the 16th western longwall of the O.F. Zasyadko Mine.

\section{Methods}

The studies were performed in accordance with developed methodology. Complex measuring stations were installed: in the roadway mined through the coal seam (4 stations) at different distances from the wall of the 16th western mining longwall towards previously worked-out pillars; and in gas drainage road (4 stations) at different distances from the longwall face. Gas-drainage road was mined vertically in the release zone of the roof in previously worked-out long-pillar of the 15 th western longwall (15 $\mathrm{m}$ from the air roadway and $7 \mathrm{~m}$ uprising in the plane of the seam).

Roof and floor stratification and displacement were measured by deep and contour reference points. Rockcracking at different distances from the roadway was determined by method of electrometry. Relative load on supports was measured by vibroacoustic method. Stress-strain state of the massif was studied by method of local hydraulic fracturing and by 
method of boreholes. Methane-air mixture consumption and methane flow rate were determinedby datagiven by the mine ventilation service.

\section{Results and discussion}

Diagrams of methane flow rate change in previously undermined massif (curve 2) and displacements of the roadway roof at different distances from the wall of the worked-out longwall towards previously worked-out long-pillars (curve 1) are shown in Figure 2. As it is seen from the diagrams, zone of active influence of mining longwall covers distance of more than $150 \mathrm{~m}$ in the direction of the previously worked-out pillars. Displacement of rock roof in this zone exceeds constructive yielding of frame support. And, on the contrary, rate of methane flow from previously worked-out massif decreases as the longwall face line approaches. It is established that roof displacement and rate of methane flow in previously worked-out pillars follow the power laws depending on distance to the worked-out longwall:

$$
\begin{aligned}
& U=1027 \cdot \ell^{-0,2} ; \\
& Q_{\mathrm{CH}_{4}}=18 \cdot \ell^{0,6},
\end{aligned}
$$

where $U$ - is displacement of the roadway roof in previously worked-out long-pillars, $\mathrm{mm} ; Q_{\mathrm{CH}_{4}}$ - is rate of methane flow from previously worked-out massif, $\mathrm{m}^{3} / \mathrm{min} ; \ell$ - is distance along the bed rise to the mining longwall, $\mathrm{m}$.

In such conditions, and in accordance with (1), it would be better to mine gas-drainage road at a distance of 160-180 $\mathrm{m}$ from the wall of the mining longwall (see Fig. 2), i.e. behind zone of high rock pressure. But then length of four breakthroughs, which, for the purpose of airing, connect bleeder entry and air roadway, should be about $170 \mathrm{~m}$, hence resulting in significantly increased cost of roadway mining and supporting.

On the other hand, bleeder entryminedimmediately after the reference pressure zone (40-50 $\mathrm{m}$ from the wall of mining longwall) will increase cost of its supporting because in such conditions, additional supporting facilities are required in order to preserve its stability.

Final decision on choosing location for the gas-drainage road is made on the basis of comparison of the following technical and economic indexes:

- increase of support costs when it is located closer to the mining longwall;

- additional costs associated with increased length of the gas-drainage boreholes and air breakthroughs if the roadway is at greater distance from the mining longwall.

Therefore, rational variant for the gas-drainage road location [6] should be chosen after comparing costs of its supporting, labour content of the process, effectiveness of mining operations and gas drainage, and, what is the most important, level of job safety for the miners.

During periods of gas-drainage road mining and operation in the pressure release zone, it is necessary to carry out a set of measures in order to prevent water inflows. Floor of the gas drainage road is subject to significant deformations due to the rock slackening during the gas-drainage borehole washing (roof swelling increases by 2.5-3.0 times). At excessive moisture saturation of the floor consisting of weak clay rocks prone to slackening and swelling, rate of swelling is intensified in zone of mining activity influence. Technological measures for reducing moisture rate in the rocks are: roadway mining at the rise angle to the floor rock bedding in order to ensure water drainage; and construction of gutters for water drainage and water collectors with automated water pumping. 


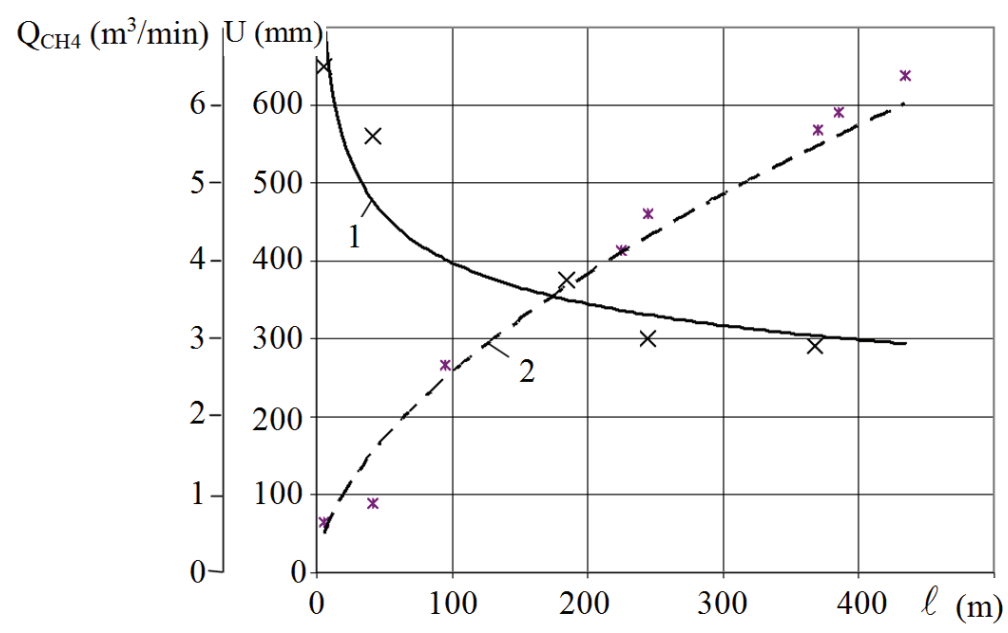

Fig. 2. Dependence of the roadway roof displacement and rate of methane flow from previously worked-out long-pillars on distance to the wall of the mining longwall: 1 - roadway roof displacement, $\mathrm{mm} ; 2$ - methane flow rate, $\mathrm{m}^{3} / \mathrm{min}$.

Significant difficulties for the roadway supportingare created by zones of tectonic disturbances such as slips, overlaps, etc. Zones of high stress are formed at different distances from the disturbance contour depending on disturbance type and amplitude; size and rate of these zonesare increased significantly when the disturbance is under the influence of miningactivity. When approaching the disturbance, deformations of the rock roof and floorare significantly increased. Therefore, appropriate measures must be taken to strengthen the roadway support before it approaches zone of combined influence of disturbances and mining operations.

In order to increase stability of gas drainageroad located in pressure release zones and tocontrol their state, it is necessary to: reduce influence of stationary reference pressure caused byconjunction of previously worked-out and working long-pillars; reducing and duration of temporary reference pressure influence in zone of mining operation influence; during further development of mining operations, to preserve previously formed pressure release zones through the use of special technological measures for controllingmanifestations of rock pressure.

\section{Conclusions}

1. In Ukraine mines, underground gas drainage from the rock-coal massif is, in most cases, carried out from preparatory roadways, which are also used in technological processes of coal mining. Such combination impedes effective performance of these works. In addition, preparatory roadways are located in zone of active influence of longwall; therefore, they are subject to significant deformations.

2. The most promising solution of the problem of increasing efficiency of the gas drainage from the massif is using of additional gas-drainage road. This method allows separating processes of coal mining and methane recovery in space and time. The main difficulty in applying such gas drainage technologies is determination of rational location for the gas-drainage road.

3. The Ukrainian normative documents provide methods for calculating zones with pressure release and high rock pressure in the massif, and it is recommended to mine the road behind zones with high rock pressure. In this case, and in difficult conditions of coal 
seam mining, distance from the road to working longwall is more than $100 \mathrm{~m}$. This distance reduces efficiency of gas drainage and is not economically feasible due to significant length of the gas-drainage boreholes and air breakthroughs. Therefore, gas-drainage road should be located as close to the working longwall as possible, but with possibility to ensure its stability during its entire service life. At the same time, it is necessary to reinforce the road support

4. Experimental studies were conducted in the O.F. Zasyadko Mine and Krasnolimanska Mine. It is established that with increasing distance from the mining longwall to the gasdrainage road location in the massif unloaded by the underworking displacement the road contour decreases, and methane flow rate increases in power dependencies. Use of these results will make calculation of the gas-drainage road rational location more accurate.

\section{References}

1. State Committee of Ukraine on Occupational Safety (2005), 10.0-1.01-05. Pravyla bezpeky u vugilnyh shahtah: Normatyvnyy dokument Minvuhlepromu Ukrainy [10.01.01-05. Safety rules in coal mines: Regulatory Document Coal Industry of Ukraine], Ukraine Ministry of Coal Industry, Kyiv, Ukraine

2. Bulat, A.F., Zviagilskiy, E.L. and Lukinov, V.V. (2004). Experimentalnaya otsenka gazopronitsaemosti podrabotannogo ugleporodnogo massiva. Nauka i obrazovanie, 3 (19), 23-128

3. Ukraine Ministry of Coal Industry (2004), 10.1.001174 088.001-2004. Dehazatsiya vuhilnykh shaht. Vymogy do sposobiv ta shem degazacii: Normatyvnyy dokument Minvuhlepromu Ukrainy. Standart [10.1.001174 088.001-2004. Degassing of coal mines. Requirements for methods and degassing schemes: Regulatory Document Coal Industry of Ukraine. Standard], Ukraine Ministry of Coal Industry, Kyiv, Ukraine

4. Ukraine Ministry of Coal Industry (1998), 12.01.01.201-98. Roztashuvannia, ohorona $i$ pidtrymannia girnychih vyrobok pid chas vidpratsiuvannia vuhilnykh plastiv na shahtah. Metodychni vkazivky: Normatyvnyy dokument Minvuhlepromu Ukrainy [12.01.01.20198. Location, protection and maintenance of mine workings during the mining of coal seams in mines. Guidelines: Regulatory Document Coal Industry of Ukraine], Ukraine Ministry of Coal Industry, Kyiv, Ukraine

5. Kurnosov, S.A. (2011). Metodichesky k opredeleniyu mesta i parametrov zalozheniya gazosbornoy vyrabotki pri degazatsionnyh rabotah v ugolnyh shahtah, Geotehnicheskaya mehanika, 92, 96-103

6. Ukraine Ministry of Coal Industry (2008), 10.1.05411357.006:2007. Dehazatsiya vuhilnykh plastiv ta vmishchuyuchykh porid z zastosuvannyam hazozbirnoï vyrobky. Skhemy dehazatsii: Normatyvnyy dokument Minvuhlepromu Ukrainy. Standart [10.1.05411357.006:2007. Degassing of coal seams and surrounding rocks using of collecting workings. Schemes degassing: Regulatory Document Coal Industry of Ukraine. Standard], Ukraine Ministry of Coal Industry, Kyiv, Ukraine 